Ronald Siu, MPH

Wajih Bukhari, MBBS

Angela Todd, MSc

Wendy Gunn, BSc

Qiu Sue Huang, PhD

Paul Timmings, MD

\section{ACUTE ZIKA INFECTION WITH CONCURRENT ONSET OF GUILLAIN-BARRÉ SYNDROME}

Case report. A 47-year-old Tongan male returning to New Zealand after a 2 -week holiday in Tonga presented with 3 days of progressive limb weakness, numbness, unsteady gait, and dyspnea. Two days before departing Tonga (6 days before neurologic symptoms), he developed leg swelling with erythematous and pustular lesions, which were treated with flucloxacillin. He had no medical history, was not taking regular medication, and had a 20 pack-year smoking history.

Examination findings included the following: afebrile, pulse 80 beats $/ \mathrm{min}$, blood pressure 150/90 mm $\mathrm{Hg}$, respiration 20 breaths/min, and oxygen saturation 98\% (air). Cardiovascular and abdominal examinations were unremarkable. Cranial nerves and eye movements were normal. Limbs were hypotonic with globally reduced power (4/5), areflexia, and absent plantar responses. Temperature and pain sensation were impaired in hands and feet. Proprioception and vibratory sensation were impaired in the feet. Romberg test was positive.

Full blood count, renal function, electrolytes, creatinine kinase, hemoglobin $A_{1 c}$, C-reactive protein, thyroid function, $\mathrm{B}_{12}$, and folate were normal. Liver enzymes were mildly elevated (ALP 122, GGT 251, and ALT 41 IU/L). Antinuclear antibody was 1:160. CSF showed albuminocytologic dissociation: protein $0.69 \mathrm{~g} / \mathrm{L}$ (reference $0.15-0.45$ ), white blood cells $2 / \mu \mathrm{L}$, red blood cells $1 / \mu \mathrm{L}$, and glucose $3.4 \mathrm{mmol} / \mathrm{L}$ (serum glucose 6.0). Spine MRI and chest $\mathrm{x}$-ray were unremarkable. Normal cranial MRI excluded concurrent acute disseminated encephalomyelitis. Nerve conduction study on day 2 of admission revealed demyelinating, predominantly motor, polyneuropathy (table).

Serum reverse transcription (RT)-PCR on day 3 after illness onset was negative for chikungunya and dengue RNA and positive for Zika RNA (subsequently negative on day 13). Dengue NS1 antigen (Platelia Dengue NS1; Bio-Rad, Hercules, CA) was negative. Immunoglobulin (Ig)M antibodies (low level) and IgG antibodies (high level) against Zika (EUROIMMUN, Luebeck, Germany) and dengue (PanBio, Brisbane, Australia) were detected on day 3. CSF RT-PCR on day 5 was negative for all 3 viruses.

\section{Clinical/Scientific Notes}

A diagnosis of Guillain-Barré syndrome (GBS) was made. Worsening respiratory function required ventilation support. Five days of Ig was given $(0.4 \mathrm{~g} / \mathrm{kg} / \mathrm{d})$. Serial quantitative neurologic examination showed a steady decline. He was then given 6 plasma exchanges beginning 5 days after the last dose of Ig, i.e., from day 10 of treatment. Respiratory status improved to not requiring mechanical ventilation by day 21 . At day 33, when transferred to rehabilitation, he had persistent limb weakness with best power grade $3 / 5$ and remained bedbound.

Discussion. This case illustrates rapid development of severe acute demyelinating polyneuropathy linked with Zika virus infection. The pustular leg spots were probably infected mosquito bites, although the erythematous skin lesions may have also been related to Zika infection. There are no case reports of Zika-related GBS in New Zealand. There are reports of GBS associated with Zika infection in French Polynesia, South Pacific islands, and South and Central America. ${ }^{1}$ It is noteworthy in our case that Zika was detected by PCR in the serum while his clinical status was worsening. RT-PCR for Zika is sensitive and detects viral RNA concentrations as low as 900 copies/mL with high specificity and no cross-reactivity to other flaviviruses including dengue, West Nile, and chikungunya. ${ }^{2}$ Although the underlying mechanism remains unclear, GBS has been associated with other flaviviruses (dengue, ${ }^{3}$ West Nile virus, ${ }^{4}$ etc.). In this case, we demonstrated no evidence of direct CNS infection (negative CSF Zika PCR and normal cranial MRI) but clear evidence of simultaneous systemic Zika infection contemporaneous with the appearance of GBS.

Serologic cross-reactivity between flaviviruses means that currently available IgM antibody assays cannot reliably distinguish between Zika and dengue. ${ }^{5}$ The PCR and serology results suggested that the patient had a likely secondary flavivirus infection-a recent Zika virus infection in the context of preexisting anti-dengue antibody.

Unlike recent GBS case reports from 2014 to 2016 with only positive Zika serology ( $\operatorname{IgM})$, our case is of particular interest because Zika virus was present in the serum at the same time that GBS was developing. This suggests either direct neural injury by Zika or 
Table Nerve conduction study

\begin{tabular}{|c|c|c|c|c|c|c|}
\hline Type of study & Nerve/site, right & Recording site & Latency, ms & Amplitude, $\mu \mathrm{V}$ & Distance, $\mathrm{cm}$ & Velocity, $\mathrm{m} / \mathrm{s}$ \\
\hline Sensory & Median/wrist & Digit II & 3.91 & 6.6 & 13 & 43.0 \\
\hline Sensory & Ulnar/wrist & Digit V & 3.07 & 5.8 & 11 & 49.1 \\
\hline Sensory & Sural/calf & Lateral malleolus & 3.75 & 16.3 & 14 & 48.9 \\
\hline Motor & Median/wrist & APB & 13.54 & 0.5 & 7 & \\
\hline Motor & Ulnar/wrist & ADM & 6.88 & 2.3 & 6.5 & \\
\hline Motor & Ulnar/below elbow & ADM & 11.72 & 1.1 & 25 & 51.6 \\
\hline Motor & Ulnar/above elbow & ADM & 13.80 & 1.7 & 14 & 67.2 \\
\hline Motor & Common peroneal/ankle & EDB & 12.60 & 0.9 & 9 & \\
\hline Motor & Tibial/knee & $\mathrm{AH}$ & 20.36 & 0.8 & 44 & 41.6 \\
\hline F wave & Median/wrist & APB & No response & & & \\
\hline F wave & Ulnar/wrist & ADM & No response & & & \\
\hline F wave & Common peroneal/ankle & EDB & No response & & & \\
\hline F wave & Tibial/knee & $\mathrm{AH}$ & No response & & & \\
\hline
\end{tabular}

Abbreviations: $\mathrm{ADM}=$ abductor digiti minimi; $\mathrm{AH}=$ abductor hallucis; $\mathrm{APB}=$ abductor pollicis brevis; $\mathrm{EDB}=$ extensor digitorum brevis.

rapid cellular-mediated response to Zika "molecular mimicry" with cross-reactivity against peripheral nerve, rather than an Ig-mediated mechanism, which would usually show a latent period. Flaviviruses are neurotropic, but, neuroinvasion processes are not fully understood. Neuronal virus attachment factors for Zika in the peripheral nervous system may be similar to those for West Nile virus, which are at the sensory nerve endings. ${ }^{6}$ After entering the neuron, the virus may then utilize axonal transport to spread in retrograde and anterograde directions. ${ }^{7}$ These postulated mechanisms may in part explain rapidity of onset of Zika-associated GBS, but further study is needed because there are no definitive data.

From the Department of Neurology (R.S., W.B., P.T.), Waikato Hospital, Hamilton; and Arbovirus Reference Laboratory (A.T., W.G., Q.S.H.), Institute of Environmental Science and Research, Wellington, New Zealand.

Author contributions: Ronald Siu: drafted and edited the manuscript. Wajih Bukhari and Paul Timmings: reviewed and edited the manuscript. Angela Todd: performed real-time RT-PCR, interpreted the results, and critically reviewed the manuscript. Wendy Gunn: conducted serologic testing, interpreted the results, and critically reviewed the manuscript. Qiu Sue Huang: interpreted the results and critically reviewed the manuscript.

Study funding: No targeted funding reported.

Disclosure: The authors report no disclosures relevant to the manuscript. Go to Neurology.org for full disclosures.
Received February 25, 2016. Accepted in final form June 28, 2016.

Correspondence to Dr. Siu: ronaldsiu@alumni.unimelb.edu.au or Dr. Timmings: paul.timmings@xtra.co.nz

(C) 2016 American Academy of Neurology

1. Cao-Lormeau VM, Blake A, Mons S, et al. Guillain-Barré syndrome outbreak associated with Zika virus infection in French Polynesia: a case-control study. Lancet 2016;387: 1531-1539.

2. Lanciotti RS, Kosoy OL, Laven JJ, et al. Genetic and serologic properties of Zika virus associated with an epidemic, Yap State, Micronesia, 2007. Emerg Infect Dis 2008;14: 1232-1239.

3. Esack A, Teelucksingh S, Singh N. The Guillain-Barré syndrome following dengue fever. West Indian Med J 1999;48: 36-37.

4. Ahmed S, Libman R, Wesson K, Ahmed F, Einberg K. Guillain-Barré syndrome: an unusual presentation of West Nile virus infection. Neurology 2000;55:144-146.

5. Revised diagnostic testing for Zika, chikungunya, and dengue viruses in US Public Health Laboratories: memorandum, Centers for Disease Control and Prevention, Division of Vector-Borne Diseases. 2016. Available at: http://www. cdc.gov/zika/pdfs/denvchikvzikv-testing-algorithm.pdf. Accessed April 16, 2016.

6. Lim SM, Koraka P, Osterhaus AD, Martina BE, West Nile virus: immunity and pathogenesis. Viruses 2011;3:811-828.

7. Neal JW. Flaviviruses are neurotropic, but how do they invade the CNS? J Infect 2014;69:203-215. 


\title{
Neurology
}

\author{
Acute Zika infection with concurrent onset of Guillain-Barré Syndrome \\ Ronald Siu, Wajih Bukhari, Angela Todd, et al. \\ Neurology 2016;87;1623-1624 Published Online before print July 27, 2016 \\ DOI 10.1212/WNL.0000000000003038
}

This information is current as of July 27, 2016

Updated Information \&
Services

References

Citations

Subspecialty Collections

Permissions \& Licensing

Reprints including high resolution figures, can be found at: http://n.neurology.org/content/87/15/1623.full

This article cites 6 articles, 1 of which you can access for free at: http://n.neurology.org/content/87/15/1623.full\#ref-list-1

This article has been cited by 2 HighWire-hosted articles: http://n.neurology.org/content/87/15/1623.full\#\#otherarticles

This article, along with others on similar topics, appears in the following collection(s):

All clinical neurophysiology

http://n.neurology.org/cgi/collection/all_clinical_neurophysiology

All Infections

http://n.neurology.org/cgi/collection/all_infections

Guillain-Barre syndrome

http://n.neurology.org/cgi/collection/guillainbarre_syndrome

Peripheral neuropathy

http://n.neurology.org/cgi/collection/peripheral_neuropathy

Public health

http://n.neurology.org/cgi/collection/public_health

Viral infections

http://n.neurology.org/cgi/collection/viral_infections

Information about reproducing this article in parts (figures,tables) or in its entirety can be found online at:

http://www.neurology.org/about/about_the_journal\#permissions

Information about ordering reprints can be found online:

http://n.neurology.org/subscribers/advertise

Neurology ${ }^{\circledR}$ is the official journal of the American Academy of Neurology. Published continuously since 1951, it is now a weekly with 48 issues per year. Copyright ( 2016 American Academy of Neurology. All rights reserved. Print ISSN: 0028-3878. Online ISSN: 1526-632X.

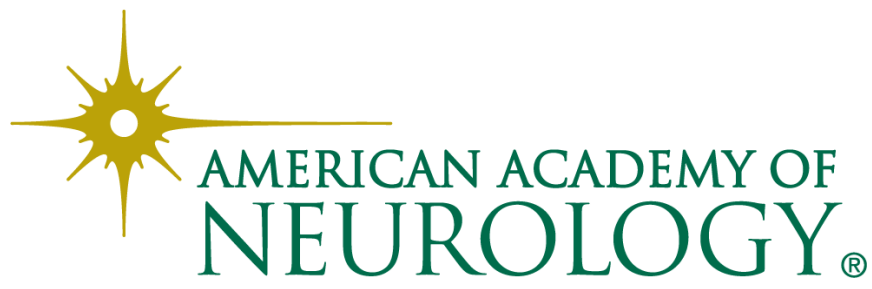

